\title{
The Tremaine Medal \\ La Médaille Marie Tremaine
}

The Marie Tremaine Medal is awarded annually by the Bibliographical Society of Canada / Société bibliographique du Canada for outstanding service to Canadian bibliography and for distinguished publication in either English or French in that field, preferably to a member of the Society or to a Canadian citizen. Members of the Council of the Society are not eligible for the award while they are in office. The Tremaine Medal Committee invites nominations for this award.

Previous recipients of the Tremaine Medal have been Marie Tremaine, 1970; John Hare and Jean-Pierre Wallot, 1973; Bruce Braden Peel, 1975; William F.E. Morley, 1977; Reginald Eyre Watters, 1979; Olga Bernice Bishop, I981; Alan F.J. Artibise, 1983; Douglas Grant Lochhead, 1985; Agnes Celia O'Dea, I987; Sandra Alston, 1988; Claude Galarneau, 1990; and Patricia Fleming, 1992.

La Société bibliographique du Canada / Bibliographical Society of Canada attribue la Médaille Marie Tremaine tous les ans pour services exceptionnels rendus à la cause de la bibliographie canadienne et pour des publications de haute qualité dans ce domaine, soit en français, soit en anglais, préférence étant accordée aux membres de la Société et aux citoyens canadiens. Les membres du Conseil de la Société ne sont pas admissibles pendant les années de leur mandat. La Comité de sélection de la Médaille Marie Tremaine sollicite des candidatures pour le concours.

La Médaille Tremaine a précédemment été décernée à Marie Tremaine, 1970; John Hare et Jean-Pierre Wallot, 1973; Bruce Braden Peel, 1975; William F.E. Morley, 1977; Reginald Eyre Watters, 1979; Olga Bernice Bishop, 198I; Alan F.J. Artibise, 1983; Douglas Grant Lochhead, 1985; Agnes Cecilia O'Dea, 1987; Sandra Alston, 1988; Claude Galarneau, I990; et Patricia Fleming, 1992. 
THE I993 TREMAINE MEDAL

At the Annual Meeting of the Bibliographical Society of Canada / Société bibliographique du Canada on I6 June I993, in Hamilton, Ontario, Joan Winearls was awarded the 1993 Marie Tremaine Medal. The following citation was read by Sandra Alston, the President of the Society:

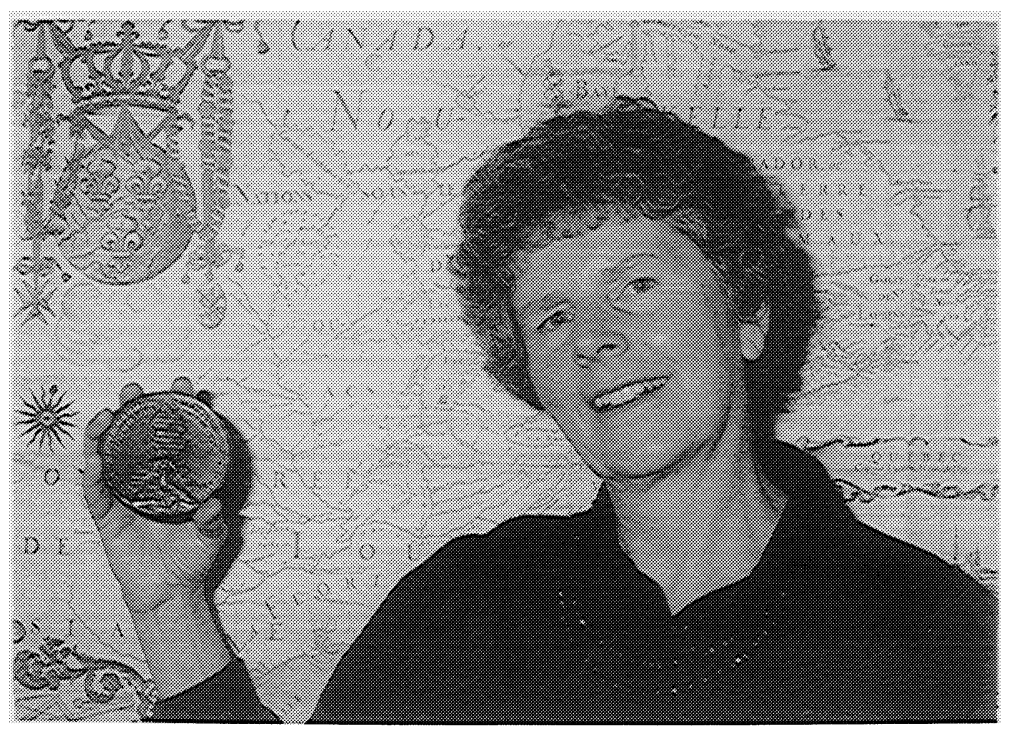

Ladies and gentlemen, the Tremaine Medal Committee takes great pleasure in its decision to award the Tremaine Medal to Joan Winearls, for her long-term and continuing commitment to cartobibliography and specifically for her book, Mapping Upper Canada, 1780-1 867: An Annotated Bibliography of Manuscript and Printed Maps (Toronto: University of Toronto Press, I99I).

Joan Winearls' long-standing interest in the history and bibliography of maps has been the focus of her career. She first joined the staff of the University of Toronto as a Map Librarian in 1964, to establish and develop a map library for the Department of Geography and for the university community. She is now the Map Librarian at Robarts Library. Joan Winearls taught the first regular course in map librarianship in Canada, as Associate Instructor at the Faculty of Library Science, University of Toronto (I970), and served as a member of the Anglo-American Cataloguing Committee for Car- 
tographic Materials (1979-82), which published Cartographic Materials: A Manual of Interpretation (1982).

Her leadership and scholarly work have been recognized on a number of occasions by academic institutions and other professional associations: the Toronto Historical Board Award of Merit (1984), the Association of Canadian Map Libraries and Archives Award (1987), and the Faculty of Library Science, University of Toronto Distinguished Graduate Award. A founding member of the Association of Canadian Map Libraries and Archives (I967), Joan Winearls has made a significant contribution as Chair of the Committee on Bibliographical Control of Cartographical Materials, resulting in the advent of the union catalogue, CartoCanadiana.

Mapping Upper Canada, I780-1867 is the work of a dedicated historian undertaken with meticulous scholarship, but its merit goes beyond its value as the definitive research tool in its field. Barbara McCorkle of Yale University has this to say of Mapping Upper Canada, 1780-1867:

Unlike bibliography, which has long had its body of rules, cartobibliography is still a field in which each player makes his or her own. Winearls has been a leader in the movement to bring cohesion and order to this anarchic situation .... (review in Cartographica 28, no. 4 (Winter I991):105-06.)

Joan Winearls has made a major contribution towards the evolving methodology of carto-bibliography, and Mapping Upper Canada, $1780-1867$ is a practical demonstration of her ideas of an appropriate carto-bibliographical format.

The following response was made by Joan Winearls:

Madame President, members of the Executive and Council, members of the Bibliographical Society of Canada, it is indeed an enormous honour to be the fourteenth recipient of the Marie Tremaine Medal for contribution to bibliography in Canada. I have been a great admirer of Marie Tremaine's work since library school where I first succumbed to the delights (and trials) of bibliography. At that time I was introduced to A Bibliography of Canadian Imprints, I75I-I800 and A Bibliography of Canadiana, and could easily forsee spending time and energy searching for those elusive materials and preparing those wonderful entries. And although in library 
school I only completed a very small bibliography on a very obscure subject (which received rather lukewarm response), I knew that I wanted to go on to do others.

The Tremaine Medal has been a very great incentive to bibliographical work in Canada, and, to me, it is certainly the most prestigious award in the field. The award has been of utmost importance in setting standards for bibliographical research and serving as an inspiration for the sloggers in the field. And the knowledge that it exists, spurs you on during those numerous moments in any large bibliographical project when your energy seems to flag.

I am particularly gratified that the Society is giving an award in a field that must to some seem very peripheral to bibliography (in the original meaning of the word), books and typography - carto-bibliography. The systematic description and listing of maps and other cartographic materials are still very much in a state of infancy in Canada. We do not even have cataloguing in our libraries and archives of more than about one-third of the maps made for this country in the last five centuries, and although there are a few published checklists and library catalogues, the identification, detailed analysis and comparison of important maps have been sadly neglected. Unfortunately, institutions and granting bodies may in future be far more interested in funding projects relating to computer-mapping and databases than they will in supporting bibliographical control for early maps. I know that your support of research in carto-bibliography in Canada will encourage others to go out and do something more for cartographic materials and perhaps for other non-book formats that are also poorly controlled bibliographically.

I am also very pleased to be in the company of the several distinguished Medal winners that have preceded me and who have inspired me greatly in my work, particularly Bruce Peel, Jean-Pierre Wallot, Douglas Lochhead, Sandra Alston, and Patricia Fleming. At the same time, I am greatly indebted to the many colleagues, both within and outside the Society, who have assisted me over the years. Thank you again for this very great honour. 